\title{
Drift macroalgae as a potential dispersal mechanism for the white abalone Haliotis sorenseni
}

\author{
Thomas B. McCormick ${ }^{1, *}$, Lorraine M. Buckley ${ }^{2}$, Jennifer Brogan ${ }^{1}$, Lyn M. Perry ${ }^{1}$ \\ ${ }^{1}$ Channel Islands Marine Resource Institute, PO Box 1627, Port Hueneme, California 93044, USA \\ ${ }^{2}$ Oxnard College, 4000 S. Rose Ave, Oxnard, California 93033, USA
}

\begin{abstract}
The endangered white abalone Haliotis sorenseni, Bartsch 1940 is distributed throughout the Southern California Bight and northern Baja California, a range of $900 \mathrm{~km}$, despite a short $5 \mathrm{~d}$ larval dispersal stage. Casual observation of 1 to $3 \mathrm{yr}$ old white abalone during routine monitoring of hatchery-raised individuals revealed behavior that may provide an alternative long-range dispersal mechanism. Two new behaviors were observed during this study. Juvenile and young adult white abalone assume a 'standing' position in response to the presence of a drifting substrate. Many then 'climb' onto fragments of drifting kelp Macrocystis pyrifera, other benthic macroalgae, and drifting substrates in flumes. Such behavior has not previously been described for any abalone species. To test the frequency and duration of the behavior, fragments of macroalgae typically found in white abalone habitat were passed down a flume stocked with juvenile and young adult white abalone. An average of more than $6 \%$ of the abalone climbed onto $M$. pyrifera during the short $20 \mathrm{~s}$ transit time of the algae down the flume. Significantly more abalone $(\mathrm{p}<0.01)$ climbed onto M. pyrifera than any other test substrate, including 2 other macroalgae species and a rubber test substrate. Trials with red abalone resulted in no instances of standing or climbing behavior. Duration of white abalone attachment on kelp suspended in the water column in the laboratory was prolonged (up to $51 \mathrm{~d}$ in tests). Such behavior in the wild could result in transport distance of 100s of $\mathrm{km}$. The movement of the drift algae may bring it and the rafting abalone to isolated rock outcrops that are adult habitat. Algal rafting could potentially transport individual or groups of juvenile and early adult abalone far beyond the range of larval dispersal.
\end{abstract}

KEY WORDS: Abalone $\cdot$ Drift algae $\cdot$ Rafting $\cdot$ Dispersal $\cdot$ Benthic fauna $\cdot$ Haliotis sorenseni

\section{INTRODUCTION}

The white abalone Haliotis sorenseni is a large gastropod in the family Haliotidae characterized by slow growth and longevity ( 35 to $40 \mathrm{yr}$ ). It inhabits rocky subtidal ocean waters off the west coast of North America from Point Conception in California, south to Punta Abreojos, Baja California, Mexico (Bartsch 1940, Cox 1960). Long recruitment intervals, site fidelity, fishing, poaching, disease, and habitat change have contributed to its decline. Surveys of historic habitat in the 1990s indicated that population densities had dropped to 1.67 to 2.73 abalone ha $^{-1}$, less than $0.1 \%$ of the estimated pre-exploitation population size (Haaker
1994, Davis et al. 1996,1998). Reviews of the status of the white abalone (Tegner et al. 1996, Hobday et al. 2000) ultimately led to its listing in 2001 as the first endangered marine invertebrate under the Endangered Species Act of 1976 (NMFS 2001).

As with other marine invertebrates with complex life cycles including planktonic larvae (Scheltema 1971, Johannesson 1988, Hohenlohe 2004), distribution of abalone species has been attributed primarily to dispersal of the planktonic larvae (Prince et al. 1988, Shepherd et al. 1992, Sasaki \& Shepherd 1995). Benthic juveniles and adults are mostly sedentary, although they are capable of moving over some distance in search of food (Shepherd 1973, Tegner \& Butler 
1985a) or to form seasonal spawning aggregations (Ino 1980, Shepherd 1986, Nie 1992). These life stages are restricted to rocky bottoms and rarely move more than $10 \mathrm{~s}$ of $\mathrm{m}$. This movement likely contributes little to abalone dispersal (Momma \& Sato 1969, Koike et al. 1970, Poore, 1972, Shepherd 1973, Beinssen \& Powell 1979). There is still sparse information for many abalone species regarding the connection between larval dispersal and gene flow to other populations. For some marine invertebrates the role of pelagic larval dispersal in population genetics may be overestimated (Burton 1983), and pelagic larval dispersal may not maintain gene flow among conspecific populations (Hedgecock 1986). Other mechanisms for dispersal may be of greater importance, especially in species such as abalone that have a relatively short larval duration. Dispersal of abalone larvae may be limited by a planktonic larval duration of $6 \mathrm{~d}$ at $15^{\circ} \mathrm{C}$ for the larvae of white abalone (T. B. McCormick \& J. Brogan unpubl. data). Drift studies in the Southern California Bight have implied that short larval lifetimes are insufficient for regular connections between island and mainland abalone populations (Tegner \& Butler 1985b) because transit times in either direction between the Channel Islands and the mainland are at least 14 to 18 d (Hobday 2000a).

Adult white abalone, like other abalone species, are dependent upon macroalgae as their main source of nutrition (Tutschulte \& Connell 1988, Karpov et al. 2001). At depths of 20 to $60 \mathrm{~m}$ they inhabit rocky reefs or solitary outcrops adjacent to the sand-rock interface (Cox 1960, Tutschulte 1976) where they have access to a supply of drifting fragments of macroalgae, hereafter called drift algae, carried by currents. Like other sedentary marine herbivores, abalone catch algae that drift within their reach by lifting the anterior portion of their foot to grasp the algae (Momma \& Sato 1969, Poore 1972, Shepherd 1973). Drift algae is often abundant in subtropical and temperate environments (Josselyn 1977, Holmquist 1994, Hobday 2000a) and may be transported over long distances by tides and currents, providing a mesoscale dispersal mechanism (Highsmith 1985, Hobday 2000b). In the Southern California Bight, macroalgae, most often the giant kelp Macrocystis pyrifera, is often ripped from rocky subtidal substrates by ocean swells and tides. Once dislodged, the kelp plants trail hold fasts and blades along the bottom until moving into deeper water. Thousands of drifting kelp rafts are found in the bight throughout the year.

Rafting on drift algae plays a role in the worldwide distribution of benthic marine invertebrates (e.g. gastropods, amphipods, echinoderms, and holothurians), many of which may brood their young and lack a larval stage (Johannesson 1988, Hobday 2000b, Hohenlohe
2004). Documented examples of such transport already exist for benthic invertebrates (Santos \& Simon 1980, Stoner 1980, Gunnill 1982, Herrnkind \& Butler 1986, Bushing 1994, Holmquist 1994, Hobday 2000b, Sponer \& Ray 2002) and fishes (Kulczycki et al. 1981). Concealment on or within drift algae may greatly reduce predation during the dispersal period (Heck \& Thoman 1981, Smith \& Herrnkind 1992, Hobday 2000b). A review by Thiel \& Gutow (2005) indicates that over 1200 species of marine and terrestrial organisms use rafting as a dispersal mechanism.

Observation of 1 to $3 \mathrm{yr}$ old white abalone raised in our hatchery revealed 2 behaviors that may provide an alternative long-range dispersal mechanism. Juvenile and young adult white abalone assume a 'standing' position in response to the presence of some drifting substrates. Many then 'climb' onto fragments of drifting giant kelp, other benthic macroalgae, and drifting substrates in flumes. Such behavior has not previously been described for any abalone species. Post-metamorphic dispersal by drifting is actively initiated by foot lifting in another species of marine gastropod (Martel \& Chia 1991, Martel \& Diefenbach 1993). Dispersal of white abalone on fragments of drift algae may be facilitated by an additional locomotor behavior following foot lifting that is used during feeding.

Behavior that enables juvenile and early adult abalone to use drift algae as a means of dispersal has not previously been documented for any of the 56 extant species of abalone. As a transport mechanism, drift algae could greatly extend the distribution of benthic stage individuals and groups of white abalone, compared to their primary locomotor behavior of gliding on a muscular foot over the benthos. Contrary to the general belief that the larval stage is the only vector for long distance dispersal, our observations revealed that young white abalone spontaneously move onto drift algae in the laboratory. The purpose of this work was to describe the rafting behaviors of small (shell length $<40 \mathrm{~mm}$ ) white abalone in the laboratory and to discuss the significance of these behaviors on white abalone population distribution and the location of adults within the benthic habitat. Specifically, laboratory experiments tested the following hypotheses: (1) there is no significant difference in frequency of rafting behavior relative to type of substrate; (2) there is no significant difference in frequency of rafting behavior relative to size of the substrate; (3) there is no significant difference in frequency of rafting behavior between white Haliotis sorenseni and red $H$. rufescens abalone; and (4) there is no significant difference in the size of young abalone relative to the duration of attachment to the rafting substrate. 


\section{MATERIALS AND METHODS}

Prior to being listed under the Endangered Species Act, adult white abalone were collected in 2000 from southern California offshore waters by the California Department of Fish and Game, brought into the Ormond Beach Mariculture Hatchery in Oxnard, California, and spawned to produce animals as the beginning of a population restoration effort (NMFS 2001) Postlarvae were fed on a mixed community of diatoms (Navicula spp., Nitzchia spp., Amphora spp.), bacteria, and monostromatic algae (Myrionema sp., Uvella spp.) (Seki 1980). Juveniles were fed giant kelp Macrocystis pyrifera, feather boa kelp Egregia menziesii, and cultivated Pacific dulse Palmaria mollis. Cultivation tanks were located outdoors under $75 \%$ shade cloth and experienced a natural photoperiod with low levels of indirect lighting at night.

White abalone drift substrate preference. Drift substrate preference was tested using an apparatus consisting of 4 plastic flumes (Wildish \& Kristmanson 1988), each $2.1 \mathrm{~m}$ in length. Each flume was $16 \mathrm{~cm}$ wide and filled with seawater to a depth of $12 \mathrm{~cm}$. New and recirculated seawater first passed through a packed column to maintain dissolved oxygen at or near saturation. Water then passed through a series of baffles that resulted in laminar flow as it entered the 4 flumes. Water from the flumes flowed to a holding tank, where it was pumped by a $1.5 \mathrm{hp}$ pump back to the packed column. Filtered seawater was added to the system at a rate of $57 \%$ system volume $h^{-1}$, preventing the build up of metabolites. Seawater velocity in each flume was $10 \mathrm{~cm} \mathrm{~s}^{-1}$, a speed within the range measured in other drift algae environments (Holmquist 1994) and for flows measured in the California Current in southern California (Brink \& Muench 1986). Once placed in the head of each flume, drift substrates took $20 \mathrm{~s}$ to pass down the $2 \mathrm{~m}$ test section. Dissolved oxygen concentrations were consistently above $95 \%$ saturation. Seawater temperature ranged from 15.3 to $17.3^{\circ} \mathrm{C}$. Flumes were located indoors; the only light source during trials was a red $25 \mathrm{~W}$ incandescent light bulb suspended $1.4 \mathrm{~m}$ above the top of the flume to approximate nocturnal conditions as closely as possible. Flumes were drained and air dried between nightly trials. Tests were conducted over a period of 2 wk in April 2003 and again in November 2006.

For each flume trial, 400 hatchery-raised abalone were randomly selected from a culture tank holding 2000 white abalone, each 16 to $40 \mathrm{~mm}$ in shell length $(0.6$ to $7.0 \mathrm{~g}$ total wet weight ind. ${ }^{-1}$ ). After sunset, a period when abalone are most active (Uki 1981), 100 abalone were randomly placed in each of the 4 flumes and allowed to acclimate for $30 \mathrm{~min}$ prior to the first trial. The density of abalone in the flume, equivalent to 125 abalone $\mathrm{m}^{-3}$, was high to ensure that some abalone would come in contact with the drifting substrate as it brushed against the bottom and sides of the flumes. Four drift substrates were tested: 3 brown algae including 2 that are consumed by abalone (giant kelp Macrocystis pyrifera and feather boa kelp Egregia menziesii); 1 not consumed by abalone, Cystoseira osmundacea; and 1 synthetic, a flat piece of black butyl rubber (bicycle tire tube) similar in size and shape to a blade of giant kelp. A large and small version of each test substrate was used; the size was standardized on the basis of the mean wet weight of single or double $M$. pyrifera blades including pneumatocyst and connecting stipe (total weight was 13 or $25 \mathrm{~g}$ respectively). Equivalent wet weights of E. menziesii, C. osmundacea, and rubber were used. White abalone readily consume M. pyrifera and E. menziesii in our hatchery but neither C. osmundacea nor (presumably) rubber. Test substrates were released at the head of each flume and were carried by the current to the downstream end. The choice of substrate type and size for each trial was randomized, resulting in 60 to 160 trials of each (Table 1). A trial is defined as one substrate drifting down one flume. Abalone behavior was observed and recorded during each trial. Occasionally a drift substrate was caught by multiple abalone and lodged in a stationary position. If no movement was detected within $15 \mathrm{~s}$, the drift substrate was gently pushed forward with a plastic pipette to ensure that the substrate traversed the entire flume. Each drift substrate was removed upon reaching the end of the flume. Attached abalone were counted, removed from the drift substrate, and then replaced in the flume. Fifteen minutes were allowed between trials to minimize effects of the previous trial. Abalone that had been replaced in the flumes showed behavior similar to that of animals that had not moved onto the substrates. Algae substrates were discarded after each test. Rubber substrates were rinsed in fresh water and reused. At the end of the evening's testing all abalone were returned to the culture tank.

Behavioral differences between white and red abalone. Juvenile red abalone (average $17 \mathrm{~mm}$ shell length) were tested in a second flume array to determine if they would display the same behavior as white abalone.

Table 1. Haliotis sorenseni. Number of flume trials with white abalone offered different substrates. Each trial consists of 100 abalone placed in a flume. Small pieces of substrate weighed $13 \mathrm{~g}$; large pieces weighed $25 \mathrm{~g}$

\begin{tabular}{|lcr|}
\hline \multirow{2}{*}{ Substrate type } & \multicolumn{2}{c|}{ Number of trials -} \\
\cline { 2 - 3 } & Large & Small \\
\hline Cystoseria osmundacea & 60 & 89 \\
Egregia menziesii & 65 & 85 \\
Macrocystis pyrifera & 65 & 115 \\
Rubber substrate & 75 & 160 \\
\hline
\end{tabular}


Stocking densities of 93 to 100 abalone per flume were used. Current speed, dissolved oxygen levels, and temperatures were the same as in trials with the white abalone. Only 2 substrates, Macrocystis pyrifera and the butyl rubber, were tested. Thirty-six trials were run with kelp and 12 with rubber. The clean surfaces of the flume may have an effect on mollusc behavior (Martel \& Diefenbach 1993). Flume tests were undertaken to compare behavior of red abalone on clean surfaces and on microalgae-covered fiberglass plates that had been in constant use for years. These plates closely resemble rock substrate covered with a community of diatoms, bacteria, and crustose and other types of benthic algae. White abalone of appropriate size were unavailable for testing.

Attachment duration. A laboratory test was developed to determine the time that individual white abalone would stay on a blade of kelp suspended in the water column. A blade of Macrocystis pyrifera was rinsed with freshwater to reduce possible infection from rickettsia, then tethered at the pneumatocyst with monofilament line, extending from above, at the center of the water surface in a $0.64 \mathrm{~m}$ cube-shaped tank. The blade extended downward from the floating pneumatocyst. The length of the tether was adjusted to prevent contact of the kelp blade with the tank walls or bottom. Each of 6 tanks was filled to a depth of $41 \mathrm{~cm}$ with 1331 of sand-filtered, UV-irradiated seawater. Each tank received a seawater flow of $21 \mathrm{~min}^{-1}$. An air stone provided additional oxygenation and constant mixing of the water column. Tanks were located outside with a natural day-night light cycle and covered with $80 \%$ shade cloth, simulating subsurface daylight intensity at depths of 2 to $5 \mathrm{~m}$ (Sverdrup et al. 1947). Abalone were randomly selected from culture tanks, then measured and weighed. Each trial began when a single abalone was placed on a tethered kelp blade. The abalone position on or off the kelp was noted each day. If the abalone was off the kelp, the animal and kelp were removed from the tank, which was then drained, scrubbed with a brush, rinsed with fresh water and refilled with seawater. A new blade of $M$. pyrifera and a new individual abalone were then used for the next trial. A total of 60 trials were run.

\section{RESULTS}

\section{White abalone drift substrate preference}

Once introduced to the flowing water of the flume, abalone positioned themselves on the bottom and wall surfaces throughout the length of the flume, moving or remaining stationary. As Macrocystis pyrifera floated down the flume, more than one-third of the abalone assumed a standing position, extending the body out as far as possible into the water at an approximately $90^{\circ}$ angle to the tank surface. Only the posterior $10 \%$ of the foot remained in contact with the flume. Fig. 1 illustrates this behavior. If contact was

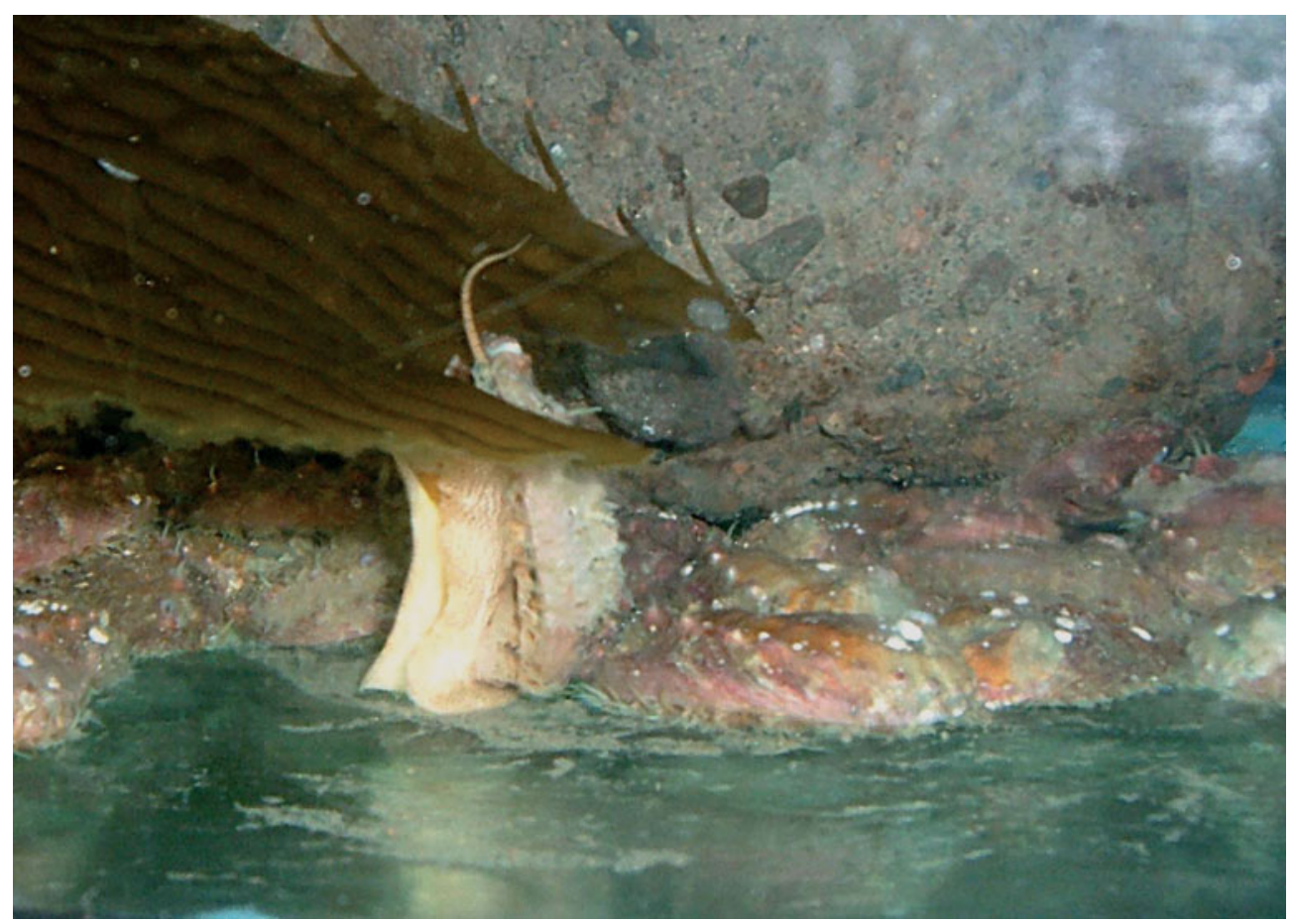

Fig. 1. Haliotis sorenseni. White abalone adapts a standing position as it prepares to climb onto a blade of giant kelp Macrocystis pyrifera 
made with the kelp, the abalone would grasp it with the anterior portion of the foot. For several seconds, the abalone grasped both kelp and the tank. Some abalone would then release their hold on the tank and quickly move onto the floating kelp, which would continue to drift down the flume. Frequency of standing behavior was dependent upon the type of test drift substrate introduced in the flume. When Egregia menziesii was introduced, fewer abalone displayed standing behavior and fewer climbed onto it than climbed onto $M$. pyrifera. There was little reaction to Cystoseria osmundacea or the rubber. Up to $41 \%$ of the abalone tested with $M$. pyrifera climbed onto the kelp blade, whereas the maximum number of abalone that climbed onto the other 2 species of algae was much lower (up to $7 \%$ for E. menziesii and up to $16 \%$ for C. osmundacea). In contrast, $3 \%$ or less climbed onto the rubber substrate. The average number of abalone that moved onto different test substrates relative to substrate size and composition is summarized in Fig. 2.

The Mantel-Haenszel procedure of analysis of proportions was used to test for homogeneity of odds ratios between different test substrates and substrate sizes. Analysis revealed that the odds ratios are not homogeneous $\left(p>0.01, \chi^{2}{ }_{[3,0.05]}=7.815\right)$; there was a significant difference in the frequency of attachment to the different test substrates. A Tukey's HSD revealed that significantly more abalone attached to Macrocystis pyrifera than any other test substrate type $(\mathrm{p}<0.01)$, whereas Egregia menziesii, Cystoseria osmundacea, and rubber were not significantly different $(p>0.3$ in all cases). To assess the effect of the size of the drift substrates on attachment frequency, a Between-

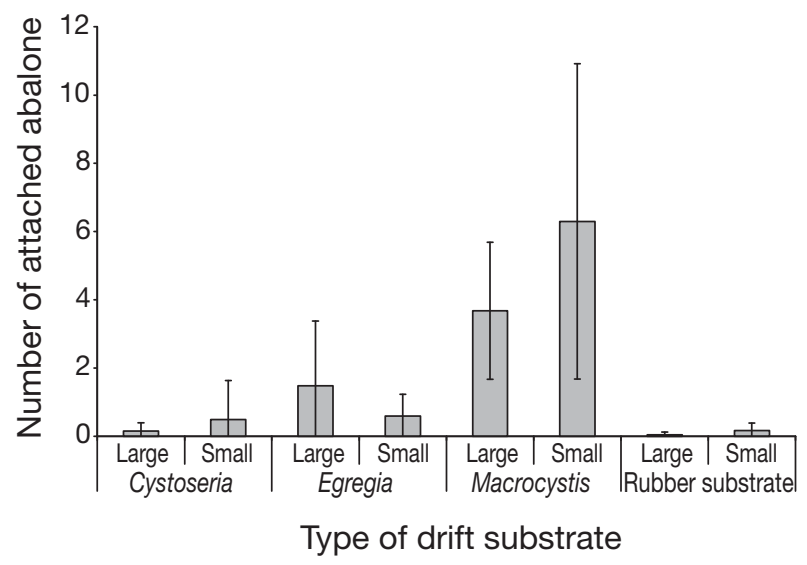

Fig. 2. Haliotis sorenseni. Number of white abalone (mean $\pm \mathrm{SD}$ ), from a pool of 100 individuals, that 'climbed' onto different test substrates drifting down a $2.1 \mathrm{~m}$ long flume at a velocity of $10 \mathrm{~cm} \mathrm{~s}^{-1}$. Controls consisted of pieces of rubber of similar size and shape to Macrocystis pyrifera blades. Small pieces of substrate weighed $13 \mathrm{~g}$; large pieces weighed $25 \mathrm{~g}$
Subjects Effects test was conducted. The analysis confirmed a significant difference among test substrates ( $p>0.01$; see Fig. 2) and revealed some difference between sizes within test substrates $(p=0.144)$. Smaller test Macrocystis and rubber substrates had more abalone.

\section{Behavioral differences between white and red abalone}

Red abalone did not display the standing behavior observed with white abalone. In 48 trials (over 4000 opportunities for an abalone to interact with the test substrates) only 2 red abalone moved toward the kelp or contacted it with their cephalic tentacles. No red abalone climbed onto the test substrates. The remainder of the abalone did not react to the approaching drift algae but did move actively about the raceway. There was no difference in red abalone behavior in flume tests comparing behavior of red abalone on clean surfaces and on microalgae-covered fiberglass plates.

\section{Attachment duration}

In tests of long-term attachment to kelp blades suspended in the water column, abalone remained on tethered kelp blades for periods up to $51 \mathrm{~d}$ in low-flow calm water laboratory conditions. The average duration on the kelp was 15 d, with $20 \%$ of the abalone remaining for $30 \mathrm{~d}$ or more (Fig. 3). Abalone consumed the kelp which they were drifting on, reducing the size of the kelp blade each day. Regression analysis showed high variability between shell length and the time spent on kelp blades $\left(\mathrm{R}^{2}=0.0386\right)$, but did show a decreasing duration on kelp as shell size increased.

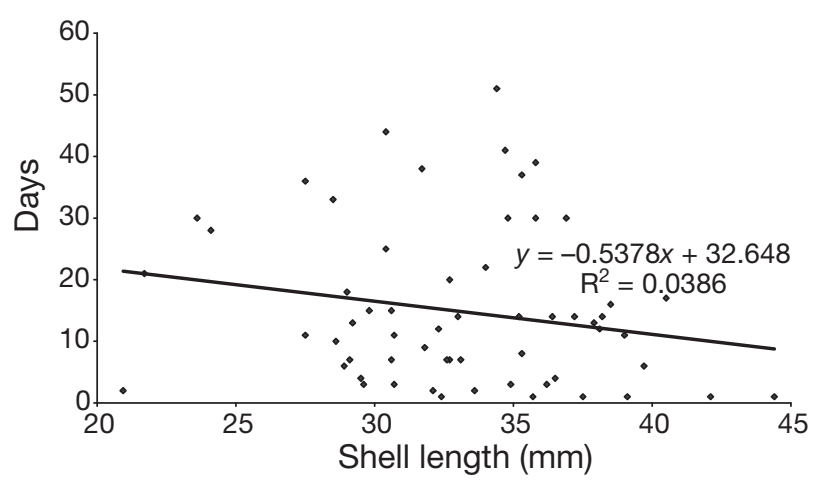

Fig. 3. Haliotis sorenseni. Duration of white abalone attachment relative to shell length when placed on a single blade of kelp suspended in the water column 


\section{DISCUSSION}

Hydrodynamics may play a role not only in the dispersal of larvae, but in the rafting of juvenile and small adult white abalone on drift algae. Drift algae is seasonally abundant in the habitat of many abalones which may position themselves to catch this passing food source (Shepherd 1973, Douros 1985). White abalone behavior may be a mechanism that results in their presence on drift algae with other species of benthic molluscs, holothurians, and arthropods that use this substrate as a dispersal mechanism in the Santa Barbara Channel and Southern California Bight (Bushing 1994, Hobday 2000a,b). Water velocities within the California Current System may exceed $20 \mathrm{~cm} \mathrm{~s}^{-1}$ during spring conditions (Nishimoto \& Washburn 2002) and nearshore eddies can exceed 30 to $45 \mathrm{~cm} \mathrm{~s}^{-1}$ in the Southern California Bight (Sverdrup et al. 1947, Anonymous 1991, Winant et al. 1991, Miller et al. 1999) for durations of several days. At those speeds, drift algae could travel 26 to $39 \mathrm{~km} \mathrm{~d}^{-1}$. Distances travelled at a more moderate $15 \mathrm{~cm} \mathrm{~s}^{-1}$ could reach $13 \mathrm{~km} \mathrm{~d}^{-1}$. At this speed, abalone that stayed on the kelp from 30 to $51 \mathrm{~d}$ could possibly be transported from 389 to $661 \mathrm{~km}$. Successful transport of kelp rafts to another kelp forest commonly extends up to $300 \mathrm{~km}$ and has been reported over 1000 km (Hobday 2000a). A large number of kelp rafts are generated throughout the year in southern California. Hobday (2000a) estimated kelp raft density in the Southern California Bight between 39000 and 348000 rafts at any given time: $45 \%$ of these rafts successfully encounter another kelp forest after an average journey of $10 \mathrm{~d}(56 \mathrm{~km})$. Kelp rafts that encounter the substrate would provide opportunities for abalone to move off the kelp onto the benthos.

Rafting on drift algae could greatly increase the dispersal distance of individuals and groups of abalone colonists, and could also reduce their susceptibility to some mortality sources, particularly predation, compared to planktonic dispersal of larvae (Holmquist 1994). Rafting on drift algae by individuals or groups of juvenile or early adult abalone increases dispersal times from days to months and dispersal distances from $10 \mathrm{~s}$ to $100 \mathrm{~s}$ of $\mathrm{km}$. In the Southern California Bight, drifting kelp rafts can persist up to $100 \mathrm{~d}$ (Hobday 2000b). In our work, once white abalone were on a kelp blade suspended in the water column, they displayed great fidelity, remaining there up to $51 \mathrm{~d}$, often until the entire blade was consumed. Increasing the size of the floating kelp from a single blade to a kelp raft would increase the time the abalone remain adrift.

Over long time scales, rafting by individuals or groups of juveniles or young adults on kelp could result in secondary recruitment at, and colonization of, distant locations. Young, reproductive white abalone
(>20 mm, McCormick \& Brogan 2003) such as those tested here in the flumes are active enough to encounter and climb onto kelp trailing from kelp paddies. Recruitment of rafting individuals could contribute to heterogeneity of existing populations. In the flume and in hatchery tanks, we observed multiple siblings raft on a single kelp blade. Rafting of young white abalone on kelp could explain the distribution of this species whose entire distribution is within and to the south of the Southern California Bight. Cyclonic onshore eddies at the extremes of the abalone's distribution may retain both larvae and kelp-rafting juveniles and small adults if they coincide with times when these life stages occur in the water column.

Transport of juvenile or small adult white abalone by drifting kelp rafts might provide a possible explanation for location of the adults within the benthic habitat. Recent surveys by Lafferty et al. (2004) and Butler et al. (2006) found white abalone at depths of 43 to $60 \mathrm{~m}$ in habitat consisting of low-relief rock outcrops or boulders interspersed with sand channels. The flow of currents in these habitats accumulates drift Macrocystis pyrifera and other algae at densities higher than the rate of net production for the surrounding area (Tutschulte \& Connell 1988). It is conceivable that ocean currents transport both the drift macroalgae and young abalone to these sites. Surveys of white abalone habitat have failed to locate juvenile animals. It is plausible that juvenile white abalone inhabit habitat that differs from that of the adults, as Seki \& Sano (1998) found for abalone in Japan. This study examined the behavior of abalone with shell lengths of 16 to $40 \mathrm{~mm}$. We anticipate that as abalone become larger this behavior will cease as the abalone become too heavy to ride on small fragments of drift kelp.

We observed the greatest number of white abalone assuming a standing behavior when Macrocystis pyrifera was introduced into the flume. Similarly, the greatest number of white abalone climbed onto $M$. pyrifera. M. pyrifera comprises the greatest benthic algae biomass in the Southern California Bight and as such is an important food source, readily consumed by both red and white abalone. It is possible that white abalone detect a biochemical cue from the approaching kelp which can trigger the standing and climbing behaviors. Our observations in the field and hatchery indicate that red abalone may also detect a biochemical cue from kelp, but do not display behaviors seen in the white abalone.

We have demonstrated that juvenile and small adult white abalone are prone to catching and riding on drift Macrocystis pyrifera under experimental conditions in the laboratory. Up to $41 \%$ with a mean of $6 \%$ of the abalone in a test flume moved onto drifting blades of M. pyrifera in less than half a minute. In the natural 
environment, abalone are nocturnally active, especially juveniles and young adults, moving out of cryptic diurnal homesites to forage in the open (Tutschulte \& Connell 1988). Once suspended on kelp in the water column, abalone could remain there for periods of time that greatly exceed the duration of the larval stage; therefore, neustonic transport could greatly exceed the distance of larval transport. Future work testing dispersal of experimental rafts with abalone or analogs having satellite tags or time-depth recorders could substantiate the behaviors we observed.

\section{CONCLUSIONS}

This is the first demonstration that juvenile and small adult white abalone display a behavior that enables them to climb onto fragments of drift algae and remain there for extended periods of time. Such behavior, while seen in other benthic invertebrates, has not been reported for any other abalone species. Similar sized red abalone displayed no behavioral response to the presence of drift algae. Once on drifting kelp, currents may carry juvenile and small adult white abalone from nursery areas to found new populations, or establish movement from one population to the next. Rafting of white abalone to new areas may be of particular importance in light of the low population densities that now exist in much their former range. Such migration of benthic juvenile or adult invertebrates may play a greater role than larval settlement in the rebuilding of populations following total defaunation (Pearson \& Rosenberg 1978, Santos \& Simon 1980). Additional laboratory studies are needed to explore factors affecting this behavior. Field work is needed to identify similar behavior in other species of abalone and to demonstrate that algal rafting occurs in coastal waters with sufficient frequency to influence distribution.

Acknowledgements. This project was supported in part by the National Sea Grant College Program of the US Department of Commerce, National Oceanic and Atmospheric Administration under NOAA Grant \#NA04OAR4170038, project \#R/F 196, through the California Sea Grant College Program, and in part by the California State Resources Agency. Support was also provided by the NOAA Habitat Restoration Program (\#DG133F-03-SE-1125) the National Fish and Wildlife Foundation (Grants 2004-0179-000, 2005-0274-000), and by Reliant Energy's Environmental Partners Program. The first flume was built by M. Newnham, C. Culver, M. Page, and J. Richards under Saltonstall-Kennedy Grants NA66FD0050 and NA86SD0069. A second flume was built by R. Kessler, who conducted additional testing with A. Serrano with support from NOAA MSI/EPP Grant No. NA050AR4811021. The authors thank G. Davis of the National Park Service for his comments on the manuscript. The views expressed herein do not necessarily reflect the views of these organizations.

\section{LITERATURE CITED}

Anonymous (1991) Ocean currents in the Santa Barbara Channel. Report for the Goleta Sanitary District, Brown \& Caldwell Consultants, Irvine, CA

Bartsch P (1940) The West American Haliotis. Proceedings of the United States National Museum 89 (3094), p 49-58

Beinssen K, Powell D (1979) Measurement of natural mortality in a population of blacklip abalone Notohaliotis ruber. Rapp PV Reun Cons Int Explor Mer 175:23-26

Brink KH, Muench RD (1986) Circulation in the Point Conception-Santa Barbara Channel Region. J Geophys Res 91: 877-895

Burton RS (1983) Protein polymorphisms and genetic differentiation of marine invertebrate populations. Mar Biol Lett 4:193-206

Bushing WW (1994) Biogeographic and ecological implications of kelp rafting as a dispersal vector for marine invertebates. In: Halvorson WL, Maender GJ (eds) Fourth California Islands Symposium: update on the status of resources. Santa Barbara Museum of Natural History, Santa Barbara, CA, p 103-110

Butler J, Neuman M, Pinkard D, Kvitek R, Cochrane G (2006) The use of multibeam benthic habitat mapping techniques to refine population estimates of the endangered white abalone (Haliotis sorenseni). Fish Bull 104:521-532

Cox KW (1960) Review of the abalone in California. Calif Fish Game 46:381-406

Davis GE, Haaker PL, Richards DV (1996) Status and trends of white abalone at the California Channel Islands. Trans Am Fish Soc 125:42-48

Davis GE, Haaker PL, Richards DV (1998) The perilous condition of white abalone Haliotis sorenseni, Bartsch, 1940. J Shellfish Res 17:871-875

Douros WJ (1985) Density, growth, reproduction and recruitment in an intertidal abalone: effects of intraspecific competition and prehistoric predation. MA thesis, University of California, Santa Barbara, CA

Gunnill FC (1982) Macroalgae as habitat patch islands for Scutellidium lamellipes (Copepoda: Harpacticoida) and Ampithoe tea (Amphipoda: Gammaridae). Mar Biol 69: 103-116

Haaker PL (1994) Assessment of abalone resources at the Channel Islands. In: Halvorson WL, Maender GJ (eds) Fourth Channel Islands Symposium: update on the status of resources. Santa Barbara Museum of Natural History, Santa Barbara, CA, p 84-95

> Heck KL Jr, Thoman TA (1981) Experiments on predator-prey interactions in vegetated aquatic habitats. J Exp Mar Biol Ecol 53:125-134

Hedgecock D (1986) Is gene flow from pelagic larval dispersal important in the adaptation and evolution of marine invertebrates? Bull Mar Sci 39:550-564

Herrnkind WF, Butler MJ (1986) Factors regulating postlarval settlement and juvenile habitat use by spiny lobsters Panulirus argus. Mar Ecol Prog Ser 34:24-30

Highsmith RC (1985) Floating and algal rafting as potential dispersal mechanisms in brooding invertebrates. Mar Ecol Prog Ser 25:169-179

- Hobday AJ (2000a) Abundance and dispersal of drifting kelp Macrocystis pyrifera rafts in the Southern California Bight. Mar Ecol Prog Ser 195:101-116

- Hobday AJ (2000b) Persistence and transport of fauna on drifting kelp (Macrocystis pyrifera) rafts in the Southern California Bight. J Exp Mar Biol Ecol 253:75-96

Hobday AJ, Tegner MJ, Haaker PL (2000) Over-exploitation of a broadcast spawning marine invertebrate: decline of the white abalone. Rev Fish Biol Fish 10:493-514 
Hohenlohe PA (2004) Limits to gene flow in marine animals with planktonic larvae: models of Littorina species around Point Conception California. Biol J Linn Soc 82:169-187

Holmquist JG (1994) Benthic macroalgae as a dispersal mechanism for fauna: Influence of a marine tumbleweed. J Exp Mar Biol Ecol 180:235-251

Ino I (1980) Abalones and their industry in Japan. In: Tomiyama T, Hibiya T, Amano S (eds) Fisheries in Japan: abalone and oyster. Japan Marine Products Photo Materials Association, Tokyo

> Johannesson K (1988) The paradox of Rockall: Why is a brooding gastropod (Littorina saxatilis) more widespread than one having a planktonic larval dispersal stage (L. littorea)? Mar Biol 99:507-513

Josselyn MN (1977) Seasonal changes in the distribution and growth of Laurencia poitei (Rhodophyceae, Ceramiales) in a subtropical lagoon. Aquat Bot 3:217-229

Karpov KA, Tegner MJ, Rogers-Bennett L, Kalvass PE, Taniguchi IK (2001) Interactions among red abalones and sea urchins in fished and reserve sites of northern California: implications of competition to management. J Shellfish Res 20: 743-753

Koike Y, Uno Y, Yamakawa H, Tsujigado A (1970) Ecological notes on the abalone Haniotis seiboldi in the marked-off area. La Mer 8:229-234

Kulczycki GR, Virnstein RW, Nelson WG (1981) The relationship between fish abundance and algae biomass in a seagrassdrift algae community. Estuar Coast Shelf Sci 12: 341-347

Martel A, Chia FS (1991) Foot-raising behavior and active participation during the initial phase of post-metamorphic drifting in the gastropod Lacuna spp. Mar Ecol Prog Ser 72:247-254

Martel A, Diefenbach T (1993) Effects of body size, water current and microhabitat on mucous-thread drifting in post metamorphic gastropods Lacuna spp. Mar Ecol Prog Ser 99:215-220

McCormick TB, Brogan JL (2003) Early reproduction in hatchery-raised white abalone, Haliotis sorenseni, Bartsch 1940. J Shellfish Res 22:825-829

Miller AJ, McWilliams JC, Schneider N, Allen JS and others (1999) Observing and modeling the California Current System. Eos Trans Am Geophys Union 80:533-539

Momma H, Sato R (1969) The locomotion behavior of the disc abalone, Haliotis discus hannai Ino, and the Siebold's abalone, Haliotis seiboldi Reeve, in the fishing grounds. Tohoku J Agric Res 20:150-157

Nie ZQ (1992) A review of abalone culture in China. In: Shepherd SA, Tegner MJ, Guzman del Proo SA (eds) Abalone of the world: biology, fisheries and culture. Wiley-Blackwell, Oxford, p 592-602

Nishimoto MN, Washburn L (2002) Patterns of coastal eddy circulation and abundance of pelagic fish in the Santa Barbara Channel, California, USA. Mar Ecol Prog Ser 241:183-199

NMFS (National Marine Fisheries Service) (2001) Endangered and threatened species: endangered status for white abalone; Final Rule. 66 FR:29046-29055, May 29, 2001 (see www.nmfs.noaa.gov)

Pearson TH, Rosenberg R (1978) Macrobenthic succession in relation to organic enrichment and pollution of the marine environment. Oceanogr Mar Biol Annu Rev 16:229-311

Poore GCB (1972) Ecology of the New Zealand abalones Haliotis species (Mollusca: Gastropoda). 2. Seasonal and diurnal movements. N Z J Mar Freshw Res 6:246-258

> Prince JD, Sellers TL, Ford WB, Talbot SR (1988) Confirmation of a relationship between localized abundance of breeding stock and recruitment for Haliotis rubra Leach (Mollusca: Gastropoda). J Exp Mar Biol Ecol 122:91-104

Santos SL, Simon JL (1980) Marine soft-bottom community establishment following annual defaunation: Larval or adult recruitment? Mar Ecol Prog Ser 2:235-241
Sasaki R, Shepherd SA (1995) Larval dispersal and recruitment of Haliotis discus hannai and Tegula spp. on Miyagi Coasts, Japan. Aust J Mar Freshw Res 46:519-529

Scheltema RS (1971) Larval dispersal as a means of genetic exchange between geographically separated populations of shallow-water benthic marine gastropods. Biol Bull 140: $284-322$

Seki T (1980) An advanced biological engineering system for abalone seed production. In: Proc Intl Symp Coastal Pacific Marine Life. Western Washington University, Bellingham, WA, p 44-54

Seki T and Sano M (1998) An ecological basis for the restoration of abalone populations. Bull Tohoku Natl Fish Res Inst 60: $23-40$

Shepherd SA (1973) Studies on the Australian abalone (genus Haliotis). I. The ecology of five sympatric species. Aust J Mar Freshw Res 24:217-257

Shepherd SA (1986) Studies on the south Australian abalone (genus Haliotis). 7. Aggressive behavior of Haliotis laevigata in relation to spawning. Mar Biol 90:231-236

> Shepherd SA, Lowe D, Partington D (1992) Studies on southern Australian abalone (genus Haliotis). XIII. Larval dispersal and recruitment. J Exp Mar Biol Ecol 164:247-260

> Smith KN, Herrnkind WF (1992) Predation on early juvenile spiny lobsters Panulirus argus (Latreille): influence of size and shelter. J Exp Mar Biol Ecol 157:3-18

Sponer R, Roy MS (2002) Phylogeographic analysis of the brooding brittle star Amphipholis squamata (Echinodermata) along the coast of New Zealand reveals high cryptic genetic variation and cryptic dispersal potential. Evolution 56: 1954-1967

- Stoner AW (1980) Perception and choice of substratum by epifaunal amphipods associated with seagrasses. Mar Ecol Prog Ser 3:105-111

Sverdrup HU, Johnson MW, Fleming RH (1947) The oceans: their physics, chemistry and general biology. Prentice-Hall, Englewood Cliffs, NJ

Tegner MJ, Butler RA (1985a) The survival and mortality of seeded and native red abalones, Haliotis rufescens, on the Palos Verdes Peninsula. Calif Fish Game 71:150-163

Tegner MJ, Butler RA (1985b) Drift-tube study of the dispersal potential of green abalone (Haliotis fulgens) larvae in the Southern California Bight: implications for recovery of depleted populations. Mar Ecol Prog Ser 26:73-84

Tegner MJ, Basch LV, Dayton PK (1996) Near-extinction of an exploited marine invertebrate. Trends Ecol Evol 11: 278-280

Thiel M, Gutow L (2005) The ecology of rafting in the marine environment. II. The rafting organisms and community. Oceanogr Mar Biol Annu Rev 43:279-418

Tutschulte TC (1976) The comparative ecology of three sympatric abalones. PhD dissertation, University of California, San Diego, CA

Tutschulte TC, Connell JH (1988) Feeding behavior and algal food of three species of abalones (Haliotis) in southern California. Mar Ecol Prog Ser 49:57-64

Uki N (1981) Feeding behavior of experimental populations of the abalone, Haliotis discus hannai. Bull Tohoku Reg Fish Res Lab 43:53-58

> Wildish D, Kristmanson DD (1988) Growth response of giant scallops to periodicity of flow. Mar Ecol Prog Ser 42:163-169

Winant CD, Bray NA, Hendershott MC, Maddox SS (1991) Analysis and acquisition of observations of the circulation on the California coastal shelf. Minutes of meeting, Quality Review Board 25 September 1991, MMS/SIO QRB No. 1, University of California San Diego, Scripps Institution of Oceanography, San Diego, CA

Submitted: May 16, 2007; Accepted: January 20, 2008

Proofs received from author(s): June 3, 2008 